\title{
A Qualitative Study of Reading Comprehension: An Insight from Pakistani Context Bridging the Needs of Engineering Students
}

\author{
Mansoor Ahmed Channa ${ }^{1}$, Zaimuariffudin Shukri Nordin ${ }^{1}$, Insaf Ali Simming ${ }^{2} \&$ Ali Asgher Chandio ${ }^{3}$ \\ ${ }^{1}$ Faculty of Cognitive Sciences \& Human Development, University Malaysia Sarawak, Malaysia \\ ${ }^{2}$ University Tun Hussein Onn Malaysia, Malaysia \\ ${ }^{3}$ Faculty of Education University of Warsaw, Poland \\ Correspondence: Mansoor Ahmed Channa, Faculty of Cognitive Sciences \& Human Development, University \\ Malaysia Sarawak, Malaysia. E-mail: mansoor.english@yahoo.com
}

Received: January 18, 2016

Accepted: March 8, 2016 Online Published: March 28, 2016

doi:10.5539/ijel.v6n2p85

URL: http://dx.doi.org/10.5539/ijel.v6n2p85

\begin{abstract}
This study aimed to investigate the teachers' opinions in terms of reading comprehension instruction to the engineering students for bridging their difficulties in reading academic text in communication subject. The study was conducted in the four engineering departments of one university in Pakistan. Semi-structured interviews of 10 teachers were used as a qualitative instrument to collect data for this study to know the needs of engineering students in terms of reading comprehension. The data was analyzed through NVivo version 8 for interpretation of the results. This study provided the most promising findings to develop reading ability among engineering students. The findings revealed that teachers should use rereading text, text scanning, and text skimming strategies to develop reading comprehension ability of engineering students.
\end{abstract}

Keywords: reading comprehension, reading strategies, academic reading, reading instruction

\section{Introduction}

In these days, reading comprehension proficiency is critical part of learning language; though the world is digitally well informed and easily accessed, engineering students cannot read and understand well the written text in academic life. Eskey (2005) asserted that students want to read texts in order to obtain information and to use it according to their needs. Similarly, Levine Ferenz \& Reves (2000) considered reading comprehension as one of the most important skills for students at university level to enhance reading academic text ability. This study has investigated reading comprehension used by teachers teaching engineering students to develop reading comprehension in Pakistan. The research transferred from getting overall familiarity about how students learned and believed about text perception in the English language. In Pakistan, English language is used as the second and medium of instruction (Channa, 2012) in all institutions related to the education; this language is also considered as the official language in the country. Similarly, multinational companies in Pakistan prefer to recruit employees having sound knowledge of reading texts as they need to be capable of reading and comprehending agreements, contracts, bonds, deals, and give-and-take official messages through emails with seniors, managers, coworkers, and in their daily businesses. Further Channa Soranastaporn Engchuan \& Tirataradol (2013) investigated needs, wants, and problems of using English by first year engineering students in QUEST, Pakistan. This study investigated the reading ability of engineering undergraduates were at a low level. The main problems in reading were: sentence structure, vocabulary in context, paragraph organization, grammatical rules (structures), prior reading and comprehending knowledge, and weak paragraph organization. The results showed that engineering students had difficulties in reading and comprehending texts.

\section{Reading Comprehension Models}

Different studies such as Taverner (1990), Aebersold \& Field (1997), and Urquhart \& Weir (1998) described reading comprehension as the most difficult area which has not been comprehended and elaborated in terms of meaning of the text. However, reading comprehension as in the words of (Urquhart \& Weir, 1998, p. 17) means "the whole parcel of cognitive activities" that readers initiate in order to comprehend the text for apprehension the correct meaning. Similarly, Taverner (1990, p. 4) defined reading comprehension for "a means of extending experience" based on the reading material which they read and perceive the actual meaning according to the text. 
Aebersold \& Field (1997) described reading a way that readers undertake by involving text material and readers through interactions. However, there are three principle reading models including bottom-up, top-down, and interactive that are used when reading a printed content. The bottom-up theory creates the fundamental aptitudes which are identified with syllables, letters, and words in content structure for starting readers. Gough (1972) has presented this theory of reading as an unraveling process on a for every letter premise. This implies that translation of such messages can be gotten from decoding the words included in the article to get the significance out of it. Accordingly, there is conceivable delicate to effortlessly overlook what the reader has comprehended from the content (Nuttall, 2000). Therefore, perception is attained by the student's understanding of each one expression used in the content. The more natural the reader with a certain expression, the more unmistakable the entire significance of the content is to him/her. This advances familiarity with reading. Besides, comprehension is attained once the reader has deciphered the significance out of each one expression through its definition, subsequently acquiring a general thought about the article. Then again, analysts are in uncertainty of its model in spite of its validity subsequent to there is a sure intricacy included the relationship between the spelling and the sound of the expression (Chen, 2002). However top-down theory of reading is used for handling cognitive perspective of reading by developing the part of foundation learning that is available in the printed content. Top-down reading theory underscores "from mind to content" (Eskey, 2005, p. 564) of readers who survey their reading methodology focusing around the content of the text by opposing the genuine substance of the content. The establishment of this model singularly lays on prior information of the readers which dismisses unmistakable substance related to the composed content (Smith, 2004). Chinwonno (2001) further specifies that a reader's current information would focus his/her perception of the content. This model turns into a powerful perspective for readers, particularly when removing the forecast, setting hints, and the principle thoughts of the content by the students. This model stresses the imperatives of having different reading materials and distinctive levels of dialect trouble that are significant to the need of the students. Conversely, the interactive model (metacognitive perspective) is used to join both bottoms up and top-down strategies for accomplished readers who have a firm understanding of reading techniques.

\section{Literature Review}

Stanovich (1980) stated that the problems in reading occur due to insufficiency of each student through the reading procedure. As the clarification of both the top down and bottom up reading courses of action has been built and a few recommendations have been made by different analysts to advance its capacity. Viable readers can attain familiarity and precision once they find themselves able to ace the fruitful utilization of each one model. An impeccable reading ability can be portrayed by its simplicity and accuracy all through the reading methodology. Therefore, to accomplish this, a standard connection of the two models ought to be kept up (Stanovich, 1980). Channa Yossatorn \& Yossiri (2012) investigated activities based language learning in one university in Thailand. The study revealed that students can develop four skills using activities with support of teachers. The findings of this study suggested that using strategies can help foreign students in medical and engineering to develop their skills including reading. Further, Channa \& Nordin (2014) examined cognitive learning methods and suggested to make it as the input to develop reading comprehension courses. The results of review study revealed that cognitive and metacognitive strategies can enhance reading comprehension of students. Interestingly, Channa \& Nordin (2015) found reading activities as the only solution to boost up apprehension of the text. This study recommended zone of proximal development theory as the possible solution to overcome barriers reading text. Similarly, Channa, Nordin, Siming, Chandio \& Koondher (2015) reviewed literature related to reading and metacognition and reported that meta-cognitive strategies including planning, monitoring, and evaluating can develop reading comprehension of students. The findings of this study revealed that teachers can scaffold students in developing reading abilities of students through metacognitive strategies.

\section{Gaps in the Reading Research}

Reviews of previous studies indicated the various main issues for this research. Firstly, very little research is existed on engineering university students as compared to the elementary, science and technology university, and either primary or high school students in terms of reading and understanding texts. Secondly, curricula is fixed in engineering university contexts, therefore very few studies are undertaken for engineering students to develop their reading comprehension. Thirdly, the elementary, science and technology, and either primary or high school students had more opportunities of reading texts as they are regularly taught in classes. Finally, further investigation is needed in order to get reading benefits achieved for better comprehension of the texts. Furthermore, Stanovich (1980) has asserted that good readers can make progress and can turn as better readers in reading achievement; whereas, low readers read less and acquire low reading proficiency. In results, the gap between high and low readers is increased in terms of reading and comprehension proficiency. However, some 
research indicated that high school or college-level readers get benefited from reading and have developed their proficiency. Therefore, this present research has to be explored whether this claim can be applied to engineering students for the development of their reading and understanding proficiency. The main objective of this study was to identify the difficulties or barriers that first year students in engineering departments face when reading texts at Pakistan; this main objective generated the research question for present study: What problems or barriers do first year engineering students find when reading texts at Pakistan?

\section{Data Collection and Analyses}

In this study, qualitative research instrument was used to find the perceptions of teachers teaching engineering student about reading comprehension as the part of communication skills subject. The instrument includes semi-structured interviews of 10 teachers in Pakistan. The main objective of this qualitative research is to identify strategies and provide a list to the students to overcome their reading and comprehending obstacles independently. The semi-structured interviews with teachers were conducted at Pakistan in April and May 2015. These interviews were recorded using audio tape and transcribed for analysis and results. Initially, the researcher analyzed the qualitative data of this research by following Strauss and Corbin (1990), and Huberman \& Miles (1994) and finally analyzed data using NVIVO version 8 which generated the final themes as given in the results section.

\section{Demographic Information}

Semi-structured interviews were undertaken with 10 teachers teaching in Pakistan ( 7 male and 3 female). The teachers involved in the interviews are those who deal with reading comprehension in read aloud sessions of engineering students. The more demographic information is given in the Table 1 below.

Table 1. Demographic iunformation

\begin{tabular}{|c|c|c|}
\hline & & $\begin{array}{l}\text { Teachers } \\
N=10\end{array}$ \\
\hline \multirow[t]{4}{*}{ Age } & $25-30$ & 4 \\
\hline & $31-35$ & 2 \\
\hline & $36-40$ & 2 \\
\hline & $41-45$ & 2 \\
\hline \multirow[t]{2}{*}{ Gender } & Male & 7 \\
\hline & Female & 3 \\
\hline \multirow[t]{3}{*}{ Education } & B.E Degree & 3 \\
\hline & Master & 4 \\
\hline & $\mathrm{PhD}$ & 3 \\
\hline \multirow[t]{4}{*}{ Length of service } & $1-5$ & 3 \\
\hline & $6-10$ & 2 \\
\hline & $11-15$ & 3 \\
\hline & $15-20$ & 2 \\
\hline
\end{tabular}

\section{Results of Interviews: Reading Comprehension}

The NVivo software version 08 was used which generated 3 main themes for reading comprehension. These themes are included as rereading, scanning, and skimming of the text (see Table 2) for the interpretation of the results.

Table 2. Final NVIVO themes

\begin{tabular}{lll}
\hline Level One Code & Level Two Codes \\
\hline Reading Comprehension & 1. & Rereading \\
& 2. & Text Scanning \\
& 3. & Text Skimming \\
\hline
\end{tabular}

\subsection{Rereading Texts}

Most informants informed that they taught the students to reread the text until they comprehend properly; because, one time reading cannot be enough for students to understand the whole article. If they only read one time and start practicing, they would make many mistakes in perceiving the meaning incorrectly. Most 
informants also informed that they taught their students to underline all the difficult terms and all important sentences that need proper attention to describe the clear meaning for the clarity of the text. One of them expressed his opinions:

“...If my students read roughly in the first reading, then they reread again and again for understanding the text but would not comprehend well. So, I teach them to read again and again till they understand difficult and complex sentences with full concentration as they would comprehend properly and accurately the context of the text..." [Informant Three]

"...I teach my students to reread the passage until they comprehend the text properly and get my students at practice in class activities and give home assignment to read and solve certain exercises on reading. In this way, they learn how to read independently and perform reading activities independently..." [Informant Six]

Interestingly, two teachers shared their own experiences of how they set reading activity in the class. They pointed out that setting a reading activity is very important and a prerequisite to effective understanding of the text in which students are asked to reread until they apprehend:

“... I suggest my students to read the text again and again by separating all those complex and difficult sentences for paying proper attention to comprehend the text and to perceive the exact meaning of the passage..." [Informant One]

“... I think...I would like to share my experience... when I teach reading a text. I asked my students to read and explain...when students fail in explaining then I tell them to read again and again and try to understand the meaning of the text and share with friends..." [Informant Four]

One of them shared about the importance of rereading and insisted to read a passage for at least four to five times for concrete meaning of the text:

“....in fact rereading is the part and partial as the effective practice for students. Students should read for at least five times...four times for better understanding. Every student should practice and support each other and similarly, teachers should guide them and motivate them..." [Informant Nine]

Conversely, one of them shared negative response in terms of rereading text and considered it as the waste of time and asserted students to practice on reading activity at home:

“...we have our own work...I mean other engineering related assignments. So, students should pay proper attention at the time of reading task...they practice at home. If they do not understand anything, teachers should guide them. If they read one article many time then they could not complete in one period. I think...it is a waste of time and chances for other students would be lost in taking part in the activity..." [Informant Two]

\subsection{Text Scanning}

In this theme, more than half of the informants revealed that the text scanning strategy is very essential to be used by students persistently at the time of reading. They scan text in order to find titles, names, the key headings, sub-headings, and important information within the text. Some of them informed that they teach their students to practice scanning strategy for getting quick understanding of the information. Two of them informed that scanning strategy can be useful for them to forecast the meaning of the text, to develop some concepts based on reading, and to cognize the general idea of the text:

“...while reading, I scan in order to look for the main idea in the text and I teach my students to do the same for better reading. Then, I say them to read it again and again to acquire the details of the text..." [Informant Two]

“...firstly, I prefer to teach my students for scanning by looking at the titles of the articles or headings and content tables. Secondly, I tell them to check the subject matter from each and every passage..." [Informant Five]

Some of the teachers believed that scanning strategy increase the attitudes and interest of students towards reading for finding the required information within due time. However, the concern among interviewees was that many of their peers did not realize the importance due to lack of scanning behavior or negative attitude or feeling toward difficult text. Two of them pointed out that scanning strategy seem very difficult for those students who had no good practice on reading comprehension. As a result they commented that students may carry on scanning before they read in detail and may not ignore the given reading tasks. A couple of examples are as follows:

“...I teach my students how to scan the entire data for comprehension at the pre-reading stage....and for knowing what is written in the text for detail reading...I also ask my students if they find any difficulty in the text. I even 
ask them to continue scanning the important data of the text..." [Informant Seven]

“...we guide students about scanning strategy and tell them that through scanning you can complete an excessive deal of materials and to find the particular piece of data...so they should apply scanning strategy for better comprehension of the text quickly before detailed reading... if they avoid scanning text strategy; they would not complete reading in due course of time and would spend lot of time in searching important information..." [Informant One]

Conversely, some teachers revealed their worries about a student who is lacking in the ability to scan the text. Their concern was about students who do not follow them and do not take part in reading tasks. Three of them noted:

"I have been in teaching profession for nearly sixteen years...one of the greatest skills students lack in reading is the scanning...this is because either they are too incompetent or too lazy to apply or read word by word..." [Informant Eight]

"Yeah....for me it is necessary for every student, if you succeed in increasing their interest in reading....they would show positive attitude even if they lack knowledge of reading method, I believe your students will follow and they would always practice if you guide them and help them..." [Informant Three]

"I suggest students to apply scanning... without reading word by word if they need to search of anything from the text....feedback is important; so I also give feedback on their performances reading activities...." [Informant Six]

\subsection{Text Skimming}

The third item of the level-two theme is the text skimming in which more than half of the informants informed that they have been using text skimming at the time of teaching on reading and comprehending in the class. Three of them revealed that they tried to teach and practice skimming the text properly in order to look over an article quickly. Most of them indicated that skimming is used to forecast the meaning of the text rapidly. So, more than half of the informants suggested that students should use this strategy when they read an article for developing speed in reading. They informed this in the following way:

“....as for as skimming is concerned, we teach our students that skimming strategy enable them to get thorough information of the text...this strategy would contribute more accurate image of the text to be read later on after getting birds' eye view of the text." [Informant One]

"Firstly...I ask my students to use skimming strategy in order to find information rapidly...and I also assert my students to verify the subject matter from each passage of the article. I arrange skimming activity for students to perform in class quickly and suggest them to read in detail after class..." [Informant Three]

"I teach my students to skim the whole article by using their eyes to see quickly to comprehend what is written in the text for quick performance... and for developing their speed in reading..." [Informant Five]

Interestingly, three other of the interviewees reported that skimming is reading technique when readers do move their eyes quickly over passages having certain purposes of apprehending the central ideas, important points, concepts and over-all summary of the text:

“....skimming.....skimming is very useful for review the text which is already read...so...I guide my students to read the titles in every paragraph of reading text completely....then they should check if there are subheadings in the article to develop students' habit....habit of noting down the relationships of the text with that of their thoughts". [Informant Two]

"I teach my students this [skimming] strategy to develop their reading comprehension.....and guide them to use skimming frequently for effective reading purposes. I also urge my students to read the text of the article through rapid use of eyes at the text....because...I believe that reading with the eyes would enable students to enhance their reading ability...." [Informant Seven]

“....I suggest my students to read the first and the last paragraph completely and quickly....and try to find clue words starting with who, what, why, when, and how for the certain answers....then...look for headings and sub-headings and make summary of the article with quick reading”. [Informant Ten]

Conversely, one informant revealed that students who lack skimming ability cannot develop reading habit and cannot take active part in reading activities. Such student actually does not follow the guidance of teacher:

“...to me... students who lack skimming in reading cannot take part in activities... and escape from reading tasks. Such students either do not follow the instructions of the teachers or they are incompetent...” [Informant Eight] 


\section{Summary of the Study}

The results of this study suggested that rereading is the most important activity to give clear picture of the text within few attempts of reading. Similarly, scanning and skimming activities can sharpen the memory of engineering students to scan reading with eyes without reading aloud to find information quickly. This study is similar in the sense of its importance in terms of comprehension development with the study of Wei (2005) who considered reading as the most essential tool for developing educational and professional achievement of students who need to apprehend text-books and articles for obtaining knowledge to support their academic studies. This study reported that reading is important in learning but most students are unable in reading texts effectively due to different reading problems. These problems can be solved when teachers use appropriate reading material to meet the needs of engineering students to expedite their reading aptitudes. Readers cannot understand long sentences in the texts due to its variety of clauses and complex forms in terms of grammatical structure. These readers also do not understand the text due to their poor background knowledge of reading. The findings of this study indicated that the engineering students should use different strategies in reading and comprehension at pre, during and post stages of reading. The results of the study also indicated that using these reading strategies can boost up reading proficiency of engineering students for their academic and professional success.

\section{References}

Aebersold, J. A., \& Field, M. L. (1997). From reader to reading teacher. Cambridge: Cambridge University Press.

Channa, M. A. (2012). Teachers' perceptions towards English language as a medium of instructions in Pakistan. Interdisciplinary Journal of Contemporary Research in Business, 4(5).

Channa, M. A., \& Nordin, Z. S. (2014). Identifying metacognitive strategies through learners' readingcomprehension: a review of related studies. Sci.Int. (Lahore), 26(5), 2457-2460.

Channa, M. A., \& Nordin, Z. S. (2015). Social cognitive theory and the zone of proximal development in the learning of reading comprehension. Sci.Int. (Lahore), 27(1), 581-585.

Channa, M. A., Nordin, Z. S., Siming, I. A., Chandio, A. A., \& Koondher, M. A. (2015). Developing ReadingComprehension through Metacognitive Strategies: A Review of Previous Studies. English Language Teaching, 8(8), 181-186. http://dx.doi.org/10.5539/elt.v8n8p181

Channa, M. A., Soranastaporn, S., Engchuan, K., \& Tirataradol, Y. (2013). A Study of Needs in Using English of Engineering Students at Quaid-E-Awam University of Engineering, Science and Technology, Pakistan. Journal of Thonburi University, 7(14), 9-19.

Channa, M. A., Yossatorn, Y., \& Yossiri, V. (2012). Students' Attitudes towards teachers' using Activities in EFL class. International Journal of Academic Research in Business and Social sciences, 2(5).

Chen, H. C. (2002). A preliminary study of Chinese EFL learners' difficulties in vocabulary learning and remedial learning strategies. Papers selected from the 17th conference of TVES Education. Taipei: Crane.

Chinwonno, A. (2001). A comparison of Thai and English reading comprehension strategies of pre-service teachers in Thailand. $\mathrm{PhD}$ dissertation, Ohio University.

Eskey, D. E. (2005). Reading in a second language. In E. Hinkel (Ed.), Handbook of Research in second languageteaching and learning (pp. 563-580). Mahwah, NJ: Lawrence Erlbaum.

Gough, P. B. (1972). One second of reading. In F. J. Kavanagh \& G. I. Mattingly (eds.), Language by ear and by eye (pp. 331-358). Cambridge, MA: MIT Press.

Huberman, A. M., \& Miles, M. B. (1994). Data management and analysis methods. Thousand Oaks CA: Sage Publications.

Levine, A., Ferenz, O., \& Reves, T. (2000). EFL academic reading and modern technology: How can we turn our students into independent critical readers? TESL-EJ, 4(4), A-1.

Livingston, J. A. (2003). Metacognition: An overview. (ERIC Document Service No. ED 414273).

Newell, A., \& Simon, J. A. (1972). Human problem solving. Englewood Cliffs, NJ: Prentice-Hall.

Nuttall, C. (2000). Teaching Reading Skills in a Foreign Language. Oxford: MacMillan Heinemann.

Smith, F. (2004). Understanding reading: A psycholinguistic analysis of reading and learning (6th ed.). Mahwah, NJ: Lawrence Erlbaum. 
Stanovich, K. E. (1980). Toward an interactive-compensatory model of individual differences in the development of reading fluency. Reading Research Quarterly, 16, 32-71. http://dx.doi.org/10.2307/747348

Strauss, A., \& Corbin, J. (1990). Basics of qualitative research. California: Sage Publications.

Taverner, D. (1990). Reading within and beyond the classroom. Milton Keynes, Philadelphia: Open University Press.

Urquhart, A. H., \& Weir, C. J. (1998). Reading in a second language: Process product and practice. New York: Addison Wesley Longman.

Wei, Y. (2005). The relationship between phonological awareness and reading ability of Thai students in English and Thai primary schools of Thailand. Curriculum \& Instruction Theses and Dissertations UM Theses and Dissertations (UMI No. 3175161). ProQuest Information and Learning: Collage Park, MD.

\section{Copyrights}

Copyright for this article is retained by the author(s), with first publication rights granted to the journal.

This is an open-access article distributed under the terms and conditions of the Creative Commons Attribution license (http://creativecommons.org/licenses/by/3.0/). 